\title{
Artemisia annua L.: agro-techniques for semi-arid environments
}

\author{
Marcello Scarcella, ${ }^{1}$ Francesco Grassi, ${ }^{1}$ Marcello Mastrorilli ${ }^{2}$ \\ ${ }^{1}$ CRA-CAR Unità di ricerca per l'individuazione e lo studio di colture ad alto reddito in ambienti \\ caldo-aridi, Lecce, Italy; ${ }^{2}$ CRA-SCA Unità di ricerca per i sistemi colturali degli ambienti caldo- \\ aridi, Bari, Italy
}

\begin{abstract}
Artemisia annua L. is an aromatic annual plant native in Asia, probably in China, and is widespread in all temperate regions. Aerial parts contain aromatic volatile oils and non-volatile sesquiterpenes used in pharmacopoeia. The most important sesquiterpene is artemisinin and its derivatives, which are used as a remedy against malaria. In the Mediterranean region, interest in cultivating Artemisia resulted in emerging industrial activities demanding local biomass with high content of artemisinin to start new production chains. The goal of this paper was to find out appropriate agro-techniques for semi-arid climate regions to be followed by local growers in order to get convenient yield in terms of biomass and artemisinin content. The specific research objectives were to test germplasm and to develop a pilot model for $A$. annua, including the main agro-techniques (plant density, nitrogen supply and irrigation requirements). Results were obtained after a two-year field study carried out in an area of Salento region. The effects of the season and of the tested cultivars were not significant. The highest biomass production ( $36 \mathrm{t} \mathrm{ha}^{-1}$ of dry biomass), associated with a high percentage of artemisinin ( $0.97 \%$ on dry weight), was achieved by using 7.3 plant $\mathrm{m}^{-2}$, and by supplying $60 \mathrm{Kg} \mathrm{N} \mathrm{ha}^{-1}$ and $150 \mathrm{~mm}$ of irrigation water.
\end{abstract}

Correspondence: Marcello Scarcella, CRA-SCA Unità di ricerca per l'individuazione e lo studio di colture ad alto reddito in ambienti caldo-aridi, via F. Calasso 3, 73100 Lecce, Italy. Tel. +39.0832 .306882 - Fax: +39.0832 .305411 . E-mail: marcello.scarcella@entecra.it

Key words: artemisinin, irrigation, Mediterranean climate, nitrogen fertilization, plant density.

Acknowledgements: the authors are thankful to Lachifarma company for the cooperation in providing seeds and in determining artemisinin contents.

Received for publication: 8 October 2011.

Accepted for publication: 22 April 2011.

CC Copyright M. Scarcella et al., 2011

Licensee PAGEPress, Italy

Italian Journal of Agronomy 2011; 6:e26

doi:10.4081/ija.2011.e26

This work is licensed under a Creative Commons Attribution NonCommercial 3.0 License (CC BY-NC 3.0).

\section{Introduction}

Artemisia annua L. (Asteraceae) is an aromatic, annual plant listed in the Chinese pharmacopoeia, as a remedy for various diseases (Hall and Clements, 1923). It has potential value as a source of artemisinin and essential oils (Simon et al., 1990). The essential oils of $A$. annua contain at least 40 volatile compounds and several non volatile sesquiterpenes (Charles et al., 1991; Woerdenbag et al., 1994; Gupta et al., 2002; Ferreira et al., 2005). Artemisinin was firstly isolated in China in 1972 and showed strong anti-malarial properties with little or no side effects (Schmid and Hofheinz, 1983; Klayman et al., 1984; Klayman, 1985; Xu et al., 1986; Balint, 2001; Efferth, 2007). For this reason in many countries the local legislation has therefore approved the use of artemisinin or extracts of $A$. annua to treat malaria. Artemisinin was also reported to be a plant inhibitor with potential as a natural herbicide (Duke et al., 1987; Chen et al., 1987; Bagchi et al., 1997). Other uses of $A$. annua have also been suggested, which would make this species attractive for the general public. In fact, the leaves of $A$. annua can be used to treat Candida infection in the mouth and its decoction has been found to be useful to treat haemorrhoids, and because of its positive effect on the immune system has been recommended for patients affected by AIDS. In addition, suffumigations can be used against colds and coughs, and seeds for the treatment of flatulence, indigestion and night sweats. The plant has become domesticated in many countries and is widely spread throughout the temperate regions (Gray, 1884; Bailey and Bailey, 1976; Simon et al., 1984; Klayman, 1993). The plant is usually single-stemmed reaching sometimes more than $2 \mathrm{~m}$ in height (Ferreira et al., 1997) (Figure 1).

Tiny yellow capitula, only 2 or $3 \mathrm{~mm}$ across, are displayed in loose panicles (Ferreira and Janick, 1995) (Figure 2).

The plant is naturally cross-pollinated by insects and wind action, which is unusual in the Asteraceae (McVaugh, 1984). Artemisinin is contained in glandular trichomes (Duke and Paul, 1993), which occur in leaves (up to 13\%), inflorescences (up to 82\%) with low levels in stems (up to 4.5\%) and none in pollen or roots (Duke et al., 1994; Ferreira and Janick, 1996). Some authors reported artemisinin being highest during pre-flowering stages (Acton et al., 1985; Liersch et al., 1986; El-Sohly, 1990; Woerdenbag et al., 1991), whereas other results showed that artemisinin reaching its peak during flowering (Singh et al., 1988; Pras et al., 1991; Morales et al., 1993; Ferreira et al., 1995; Laughlin, 1995). A wide variation in artemisinin content has been found in different genotypes (Charles et al., 1990) in the amount of $0.6-1.4 \%$ on dry weight (Delabays et al., 2001). Most of the available scientific literature on Artemisia is addressed to the characterization, isolation, synthesis and pharmacology of artemisinin and its derivatives. While artemisinin can be synthesized, it is unlikely to be economically competitive with the one naturally produced (Schmid and Hofheinz, 1983; Xu et al., 1986). As chemical studies on artemisinin and derivatives started to show advanced results about anti-malarial effect, the agronomists began to research techniques in order to improve biomass yield and artemisinin content in the cultivated plants. In particular, agronomic works started 
Table 1. Chemical-physical characteristics and soil classification according to USDA.

\begin{tabular}{lc}
\hline Coarse sand, \% & 6.4 \\
Fine sand, \% & 55.6 \\
\hline Silt, \% & 19.0 \\
Clay, \% & 15.6 \\
\hline Water content at field capacity (-0.03 MPa), \% on dry weight & 17.1 \\
Water content at wilting point (-1.50 MPa), \% on dry weight & 7.1 \\
\hline Bulk density, Kg dm ${ }^{-3}$ & 1.20 \\
Organic matter (Walkley and Black), \% & 0.7 \\
\hline N total (Kieldhal), \% & 0.08 \\
Assimilable phosphorus (Olsen), ppm & 4.35 \\
\hline Exchangeable potassium (ammonium acetate), ppm & 281.5 \\
\hline
\end{tabular}

since 1985 and considered genotypic screening (Singh et al., 1988; Pras et al., 1991; Delabays et al., 1993; Jain et al., 1996), the response of $A$. annua to plant spacing (Shock and Stieber, 1987; Simon et al., 1990; Ram et al., 1997; Greco et al., 2006), nitrogen fertilization (Simon et al., 1990; Greco et al., 2007; Davies et al., 2009), harvest time (Liersch et al., 1986; Morales et al., 1993; Laughlin, 1995; Wallaart et al., 2000; Kumar et al., 2004), and water requirement (Charles et al., 1993; Marchese, 2010). In Italy, $A$. annua is marginally cited in the most recent review on officinal plants (Marzi and De Mastro, 2008; Basso, 2009) as well as it has been moderately studied from the agronomic point of view, limited to a few data reported in technical bulletins (Greco et al., 2006; Interlandi et al., 2007). The aim of this work was to achieve a better knowledge of cultivation techniques of $A$. annua in the Mediterranean region. The interest in cultivating $A$. annua in this area derives from emerging industrial activities, which demand local biomass of Artemisia with high content of artemisinin. This paper reports the main results of a 2-year field study carried out in semi-arid environments of southern Italy in connection with a local pharmaceutical industry (Lachifarma, Zollino, in the Salento region). Since agronomic knowledge on Artemisia is lacking in the Mediterranean areas, the main agro-techniques (irrigation, $\mathrm{N}$ fertilization and plant density) will be studied independently from the other. The analysis of the interactions between agro-techniques will be the object of a further step of the research on Artemisia growing under Mediterranean climate.

\section{Materials and Methods}

The field trials were carried out in Monteroni di Lecce (Southern Italy, lat. $\mathrm{N}=40^{\circ} 33^{\prime} 20^{\prime \prime}$; long. $\mathrm{E}=18^{\circ} 10^{\prime} 27^{\prime \prime} ; 35 \mathrm{~m}$ above the sea level) on a sandy-loam soil, previously cultivated with tobacco. The main physicalchemical properties of the soil are reported in Table 1. The following agronomical features such as nitrogen rate, plant density and irrigation volumes (Table 2) were analysed for two years (2005 and 2006) and for two F1 genotypes (Pericle and Krono, patented material provided by

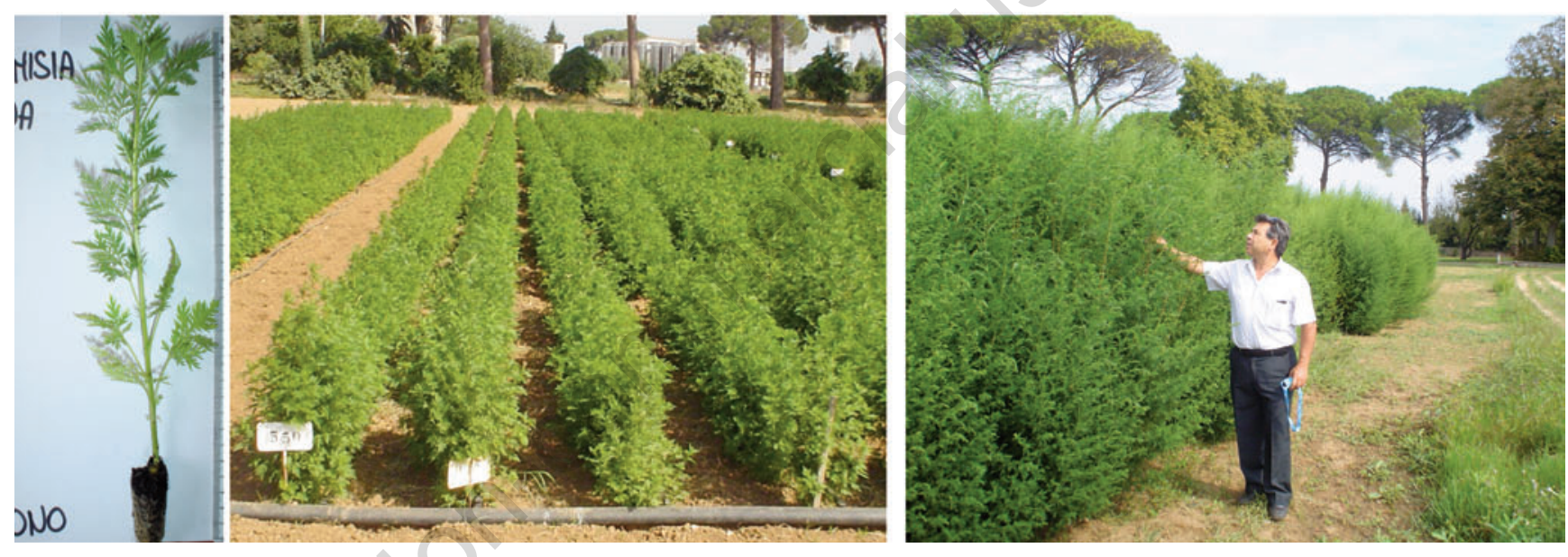

Figure 1. Artemisia at three development stages in the experimental set-up.
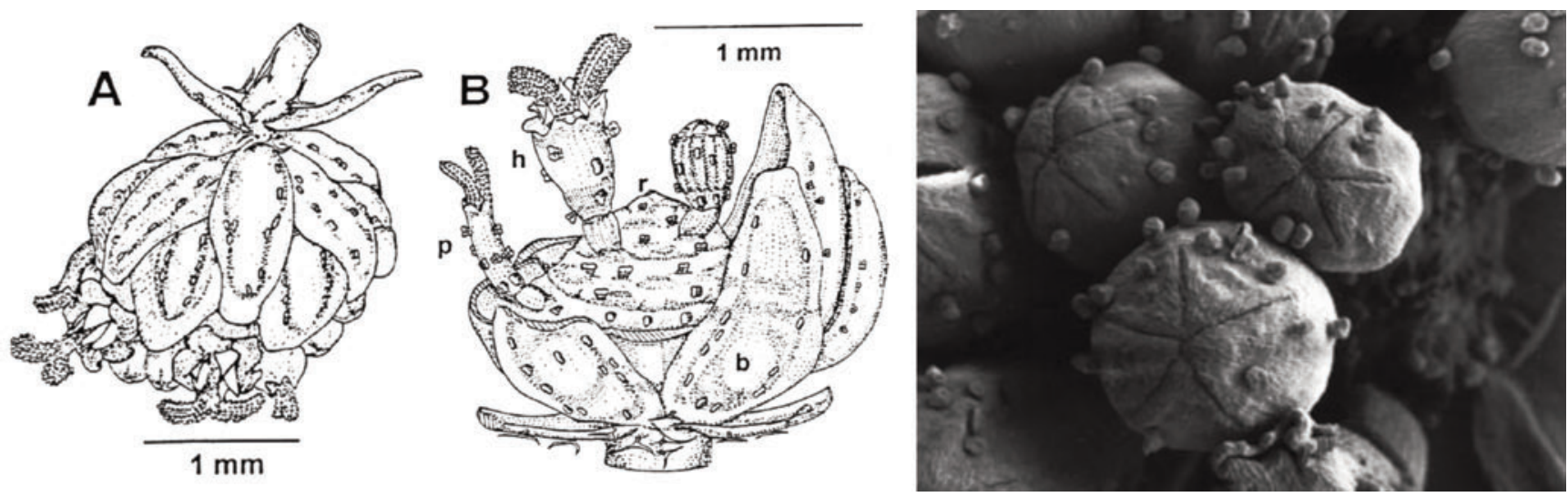

Figure 2. Floral morphology of Artemisia annua, capitula (A and B). The image shows glandular trichomes on hermaphroditic florets (from Ferreira and Janick, 1996). 
Table 2. The agronomic parameters tested in two years (2005 and 2006) and on two genotypes (Pericle and Krono).

\begin{tabular}{|c|c|c|c|c|}
\hline Studied parameter & Number of treatments & $\begin{array}{l}\text { Planting density } \\
\text { (plant } \mathrm{m}^{-2} \text { ) }\end{array}$ & $\begin{array}{l}\text { Nitrogen level } \\
\left(\mathrm{Kg} \mathrm{N} \mathrm{ha}^{-1}\right)\end{array}$ & $\begin{array}{l}\text { Irrigation volume } \\
\text { (mm) }\end{array}$ \\
\hline Planting density & 6 & $2.8,3.3,4.5,5.5,7.3$ and 11.1 & 60 & 150 \\
\hline Nitrogen level & 4 & 7.3 & $0,30,60$, and 120 & 150 \\
\hline Irrigation volume & 4 & 7.3 & 60 & $\begin{array}{c}\left(\mathrm{V}_{0}\right) \text {, at thresholds of } 40\left(\mathrm{~V}_{\mathrm{t} 40}\right), 80\left(\mathrm{~V}_{\mathrm{t} 80}\right) \text {, } \\
\text { and } 120\left(\mathrm{~V}_{\mathrm{t} 120}\right) \text { of } \Sigma \mathrm{ETC}\end{array}$ \\
\hline
\end{tabular}

Lachifarma s.r.l., Zollino, LE, Italy).

Irrigations were scheduled whenever the sum $(\Sigma)$ of the daily-calculated evapotranspiration (ETc) reached certain threshold values. Through each irrigation an amount of $30 \mathrm{~mm}$ of water was supplied to the crop. The thresholds for irrigating were: $40\left(\mathrm{~V}_{\mathrm{t} 40}\right), 80\left(\mathrm{~V}_{\mathrm{t} 80}\right)$ and 120 $\left(\mathrm{V}_{\mathrm{t} 120}\right) \mathrm{mm}$ of $\Sigma \mathrm{ETC}$. A fourth irrigation treatment $\left(\mathrm{V}_{0}\right)$ consisted in supplying $30 \mathrm{~mm}$ of water only once at the transplanting stage.

Each parameter was studied by adopting a randomized block design with 3 replications. Each elementary plot had an area of $24 \mathrm{~m}^{2}$ and plants were arranged in rows $0.55 \mathrm{~m}$ apart. In order to study each agronomic parameter independently from the other ones, the effect of the other agronomical inputs were neutralized as indicated in Table 2.

For each trial, soil was tilled before transplanting and ground fertilized with $\mathrm{P}_{2} \mathrm{O}_{5}\left(130 \mathrm{Kg} \mathrm{ha}^{-1}\right)$ and $\mathrm{K}_{2} \mathrm{O}\left(100 \mathrm{Kg} \mathrm{ha}^{-1}\right)$.

Nitrogen fertilization amount was supplied at two times: half dose in pre-planting (as ammonium sulphate, 21\%) and half dose 45 days after the transplanting (as ammonium nitrate, 26\%). Plants germinated in greenhouse in seedling tray pot at the beginning of April using one seed (seeds are very small: 11000 - 13000 seed g $^{-1}$ ) for each hole.

When seedlings under greenhouse reached $20 \mathrm{~cm}$ in high (half of May in both years) they were transplanted into the field and immediately irrigated with $30 \mathrm{~mm}$ of water. Water was supplied through a micro dripping system lying on each row. An irrigation amount of $30 \mathrm{~mm}$ was scheduled whenever the sum of calculated evapotranspiration ( $\Sigma$ ETc) reached the threshold, which varied depending on the experimental treatment (Table 2). Evapotranspiration was calculated through the evaporation-measured daily from a class $A$ pan, and adjusted by the pan factor $\left(\mathrm{K}_{\mathrm{p}}=0.8\right)$ and the crop coefficient $\left(\mathrm{K}_{\mathrm{c}}\right)$.

Since for Artemisia Kc values are not provided by the specific literature, they were estimated according to the ground covering of canopy as follows:

From transplanting to 20 days $\quad \mathrm{K}_{\mathrm{c}}=0.4$

From 21 days to $\quad 45$ days $\quad \mathrm{K}_{\mathrm{c}}=0.6$

From 46 days to $\quad 75$ days $\quad K_{c}=0.8$

From 76 days till harvest $\quad \mathrm{K}_{\mathrm{c}}=1.0$

Weeds were controlled mechanically (between rows) and manually (on rows) after 30 and 60 days from transplanting. No pest or disease occurred. During the growing period the phenological stage and the plant height were surveyed weekly on the same plants (three plants per each plot). Starting from the 45th day after transplanting, plants were weekly sampled in order to follow the variation of artemisinin content within each crop season. Samples were obtained from each elementary plot by collecting 100 grams of plant from the upper layer of canopy. The samples were air-dried and then the artemisinin content was measured in a specialized pharmaceutical laboratory (Lachifarma, Lecce, Italy), using HPLC.

\section{Results}

\section{Meteorological trend}

The meteorological trend observed (Table 3) during the crop cycles in two years was almost similar and did not influence agronomic and biometric characteristics. After transplanting the seedlings in the field, the average air temperature was always over $15^{\circ} \mathrm{C}$, and growth was not constrained by the thermal regime, while monthly rainfall (with the exception of May and September 2005) was under $30 \mathrm{~mm}$. Hence the soil water deficit was balanced by supplying irrigation during the crop cycle, according to the different water regimes, fixed by the experimental protocol.

\section{Year and genotype effects}

The final (at harvest time: beginning of October, both 2005 and 2006) plant height of Artemisia (irrigated with $150 \mathrm{~mm}$ during the crop season, at a density of 5.5 plant $\mathrm{m}^{-2}$ and fertilized with $60 \mathrm{~kg} \mathrm{~N} \mathrm{ha}^{-1}$ ) is reported in Figure 3. It shows an example of the influence of the year and genotype on plant morphology. The variance analysis $($ at $\mathrm{P}<0.05)$ does not show any significant effect (year, genotype and their interaction) on the plant height. Similarly, the observed data on biomass yield and artemisinin content are not significantly affected by year and genotype. As a consequence, in analyzing the effects of the agronomical features on yield and artemisinin, data were pooled for the two years and two genotypes.

\section{Artemisinin content during the crop cycle}

Weekly samples of plants during the flowering stage, allowed following the variation in artemisinin content in the cultivated plants. The artemisinin content increases until the full flowering and thereafter starting to decline (Figure 4). Artemisinin is contained in special glands, which are present since the early stage of development, and it accumulates as the glands reach physiological maturity. When the glands

Table 3. Monthly values of mean air temperature and rain during the Artemisia crop cycle. Long term averages are also reported.

\begin{tabular}{lcccccc} 
Month & & & & & \multicolumn{3}{c}{ Average $(1960-2004)$} \\
Rain $(\mathrm{mm})$
\end{tabular}


approach maturity they start to burst and the content is spread over the epidermis. After anthesis, the number of intact glands decreases in plants, and consequently artemisinin content does as well. We underline here that the data in Tables 4, 5 and 6 on artemisinin content refer to the seasonal peaks obtained at the full flowering stage.

\section{Plant density}

The growth of Artemisia plant in height was favoured by a density ranging from 3.3 to 7.3 plant $\mathrm{m}^{-2}$ whereas its full development was not achieved with the highest (11.1) and the lowest $\left(2.8\right.$ plant $\left.\mathrm{m}^{-2}\right)$ tested densities (Table 4). At a lower density, due to the greater space between plants, Artemisia develops in width and produces more lateral branches. While at the highest densities, less light inside the canopy increases the height development but it reduces the number of lateral branches.

Plant density affected yield (fresh and dry matter) and quality. The fresh biomass produced by the Artemisia increased significantly till a density of 7.3 plant $\mathrm{m}^{-2}$ and then declined. The decrease was even more evident in terms of dry biomass. In this case the statistical analysis revealed a clear difference between the treatments 7.3 and 11.1 plant $\mathrm{m}^{-2}$. Peak of artemisinin content showed higher values when the plant density was not higher than 4.5 plants $\mathrm{m}^{-2}$.

\section{Nitrogen rates}

Plant growth in height was favoured by nitrogen supply ranging from 30 to $60 \mathrm{Kg} \mathrm{ha}^{-1}$ while a higher rate reduced the plant heights (Table 5). The results obtained by the nitrogen $(\mathrm{N})$ fertilization experiments showed that there was a slight increase on fresh and dry biomass productions as $\mathrm{N}$ doses increased till $60 \mathrm{Kg} \mathrm{ha}^{-1}$, whereas further applications of mineral $\mathrm{N}$ did not produce any increment in biomass weight. On the contrary, higher $\mathrm{N}$ rates resulted in lower artemisinin content.

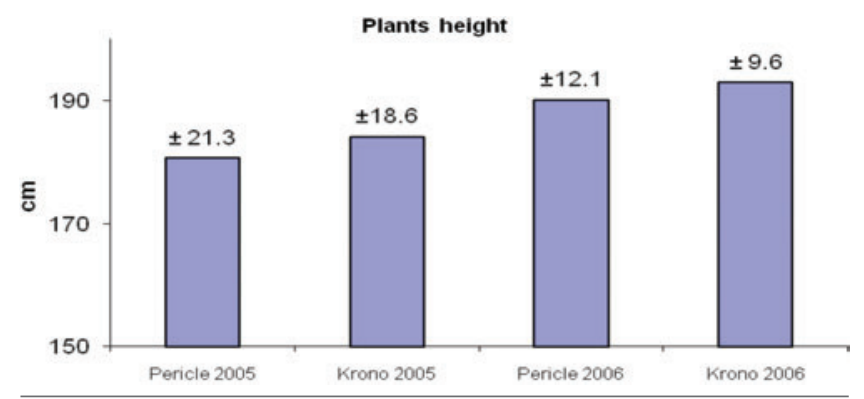

Figure 3. Plant height as affected by year and genotype. Numbers represent the standard deviations. Factors: Year, not significant; Genotype, not significant; Year $x$ Genotype, not significant.

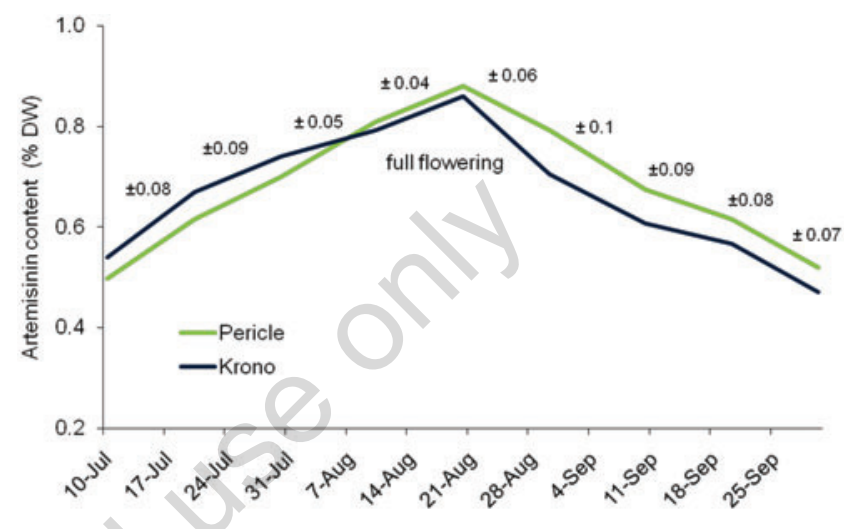

Figure 4. Evolution artemisinin content during the flowering stage. Vertical bars stand for stand deviations. Numbers represent the standard deviations.

Table 4. Biometric and productive response to planting density.

\begin{tabular}{|c|c|c|c|c|c|c|}
\hline $\begin{array}{l}\text { Density } \\
\left(p m^{-2}\right)\end{array}$ & $\begin{array}{c}\mathrm{N} \\
\left(\mathrm{Kg} \mathrm{ha}^{-1}\right)\end{array}$ & $\begin{array}{l}\text { Irrigation } \\
(\mathrm{mm})\end{array}$ & $\begin{array}{l}\text { Plant height } \\
\text { (cm) }\end{array}$ & $\begin{array}{l}\text { Fresh biomass } \\
\qquad(\mathrm{t} \mathrm{ha-1})\end{array}$ & 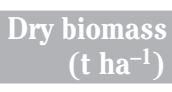 & $\begin{array}{l}\text { Maximum artemisinin content } \\
\text { ( } \% \text { on dry weight })\end{array}$ \\
\hline 2.8 & 60 & 150 & $153.4 \pm 28.5 \mathrm{C}$ & $33.6 \pm 7.6 \mathrm{~d}$ & $14.4 \pm 5.6 \mathrm{~d}$ & $0.76 \pm 0.1 \mathrm{c}$ \\
\hline 3.3 & & & $189.4 \pm 18.3 \mathrm{a}$ & $34.4 \pm 8.1 \mathrm{~cd}$ & $14.4 \pm 5.5 \mathrm{~d}$ & $0.94 \pm 0.05 \mathrm{a}$ \\
\hline 4.5 & & & $187.6 \pm 20.0 \mathrm{a}$ & $40.8 \pm 7.3 \mathrm{c}$ & $17.7 \pm 3.8 \mathrm{~cd}$ & $0.98 \pm 0.04 \mathrm{a}$ \\
\hline 5.5 & & & $162.7 \pm 17.0 \mathrm{ab}$ & $54.7 \pm 4.8 \mathrm{~b}$ & $22.1 \pm 2.6 \mathrm{c}$ & $0.79 \pm 0.8 \mathrm{bc}$ \\
\hline 7.3 & & & $201.3 \pm 17.8 \mathrm{a}$ & $66.7 \pm 3.3 \mathrm{a}$ & $28.4 \pm 1.7 \mathrm{a}$ & $0.89 \pm 0.6 \mathrm{~b}$ \\
\hline 11.1 & & 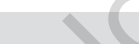 & $161.4 \pm 23.6 \mathrm{~b}$ & $64.9 \pm 3.6 \mathrm{ab}$ & $26.1 \pm 2.2 \mathrm{~b}$ & $0.76 \pm 0.9 \mathrm{c}$ \\
\hline
\end{tabular}

Within column, numbers followed by the same letter are not significantly different at $\mathrm{P} \leq 0.05$.

Table 5. Biometric and productive response to nitrogen application.

\begin{tabular}{|c|c|c|c|c|c|c|}
\hline $\begin{array}{l}\text { Density } \\
\left(\mathrm{p} \mathrm{m}^{-2}\right)\end{array}$ & $\begin{array}{c}\mathrm{N} \\
\left(\mathrm{Kg} \mathrm{ha}^{-1}\right)\end{array}$ & $\begin{array}{l}\text { Irrigation } \\
(\mathrm{mm})\end{array}$ & $\begin{array}{l}\text { Plant height } \\
(\mathrm{cm})\end{array}$ & $\begin{array}{l}\text { Fresh biomass } \\
\qquad\left(\mathrm{t} \mathrm{ha} \mathrm{a}^{-1}\right)\end{array}$ & 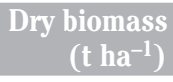 & $\begin{array}{l}\text { Maximum artemisinin content } \\
\text { ( } \% \text { on dry weight) }\end{array}$ \\
\hline \multirow[t]{4}{*}{7.3} & 0 & 150 & $171.5 \pm 20.6 \mathrm{~b}$ & $37.2 \pm 6.1 \mathrm{~b}$ & $16.5 \pm 3.6 \mathrm{~b}$ & $0.89 \pm 0.08 \mathrm{ab}$ \\
\hline & 30 & & $184.6 \pm 30.2 \mathrm{a}$ & $35.8 \pm 5.8 \mathrm{~b}$ & $16.3 \pm 3.9 \mathrm{~b}$ & $0.96 \pm 0.03 \mathrm{a}$ \\
\hline & 60 & & $184.0 \pm 23.8 \mathrm{a}$ & $47.5 \pm 4.0 \mathrm{a}$ & $20.4 \pm 2.2 \mathrm{a}$ & $0.86 \pm 0.09 \mathrm{ab}$ \\
\hline & 120 & & $163.9 \pm 17.6 \mathrm{~b}$ & $47.3 \pm 3.7 \mathrm{a}$ & $19.7 \pm 2.4 \mathrm{a}$ & $0.76 \pm 1.0 \mathrm{~b}$ \\
\hline
\end{tabular}

Within column, numbers followed by the same letter are not significantly different at $P \leq 0.05$.

Table 6. Biometric and productive response at different irrigation volume.

\begin{tabular}{|c|c|c|c|c|c|c|}
\hline $\begin{array}{l}\text { Density } \\
\left(\mathrm{p} \mathrm{m}^{-2}\right)\end{array}$ & $\begin{array}{c}\mathrm{N} \\
\left(\mathrm{Kg} \mathrm{ha}^{-1}\right)\end{array}$ & $\begin{array}{l}\text { Irrigation } \\
\text { (mm) }\end{array}$ & $\begin{array}{l}\text { Plant height } \\
\text { (cm) }\end{array}$ & $\begin{array}{l}\text { Fresh biomass } \\
\qquad\left(\mathrm{t} \mathrm{ha}^{-1}\right)\end{array}$ & $\begin{array}{r}\text { Dry biomass } \\
\left(\mathrm{t} \mathrm{ha}^{-1}\right)\end{array}$ & $\begin{array}{l}\text { Maximum artemisinin content } \\
\text { (\% on dry weight) }\end{array}$ \\
\hline \multirow[t]{4}{*}{7.3} & 60 & $\mathrm{~V}_{0}$ & $150.0 \pm 24.6 \mathrm{~b}$ & $38.4 \pm 5.2 \mathrm{~b}$ & $20.7 \pm 4.7 \mathrm{c}$ & $0.83 \pm 0.06 \mathrm{~b}$ \\
\hline & & $V_{t 120}$ & $184.4 \pm 14.9 \mathrm{a}$ & $64.9 \pm 7.0 \mathrm{a}$ & $36.1 \pm 2.4 \mathrm{a}$ & $0.97 \pm 0.02 \mathrm{a}$ \\
\hline & & $\mathrm{V}_{\mathrm{t} 80}$ & $169.1 \pm 17.4 \mathrm{ab}$ & $48.9 \pm 6.1 \mathrm{ab}$ & $28.2 \pm 3.6 \mathrm{~b}$ & $0.82 \pm 0.09 \mathrm{~b}$ \\
\hline & & $V_{t 40}$ & $166.9 \pm 18.3 \mathrm{ab}$ & $48.6 \pm 5.8 \mathrm{ab}$ & $26.4 \pm 3.9 \mathrm{~b}$ & $0.75 \pm 1.1 \mathrm{c}$ \\
\hline
\end{tabular}

Within column, numbers followed by the same letter are not significantly different at $P \leq 0.05$. 


\section{Irrigation scheduling and management}

The amount of seasonal irrigation volume was in both years 30,150 , 240 and $480 \mathrm{~mm}$ for $\mathrm{V}_{\mathrm{t} 0}, \mathrm{~V}_{\mathrm{t} 120}, \mathrm{~V}_{\mathrm{t} 80}$ and $\mathrm{V}_{\mathrm{t} 40}$, respectively.

The development in height of the Artemisia plants was constrained by the rain-fed regime: $150 \mathrm{~cm}$ in height if crop received only one irrigation at transplanting, while plants irrigated more frequently showed a taller canopy. Significant differences in fresh biomass resulted only between the rain-fed $\left(V_{t 0}\right)$ and the irrigated treatments, while the different irrigation strategies $\left(\mathrm{V}_{\mathrm{t} 40}, \mathrm{~V}_{\mathrm{t} 80}\right.$ and $\left.\mathrm{V}_{\mathrm{t} 120}\right)$ did not provide significant differences (Table 6). In terms of dry matter, the highest production was obtained by supplying $150 \mathrm{~mm}$ of irrigation water during crop cycle, whereas higher amounts of irrigation water resulted in lowered dry biomass (Table 6). The artemisinin content increased from 30 to $150 \mathrm{~mm}$ of irrigation then decreased with higher values of irrigation.

\section{Discussion}

This research has been realized for ascertained interest of some Italian pharmaceutical industries on local biomass of $A$. annua with high artemisinin content, in order to start a production chain of anti-malarial medicine that has a large request in undeveloped country, where malaria is still a serious problem to face. Lacking of information about suitability of $A$. annua in southern Italy areas bring Italian agronomic research institutes to start field trials in order to find out and perform a pilot model for A. annua that could be followed by local growers. Farmers, in the last years, are facing a large agricultural crisis and therefore this Artemisia cultivation could be a possible alternative to obtain higher incomes through diversification of the traditional agricultural productions.

It should be underlined that Artemisia crop can be easily introduced in the semi-arid cropping system environment, if supplementary irrigation is possible. Unfortunately, the lack of $A$. annua breeding specific for Mediterranean countries is a major problem to solve, in order to maximize biomass and artemisinin production in this particular area. Furthermore, the genotypes suitable for cultivation are patented by Pharmaceutical industries, and this event could limit the beginning and the development of Artemisia cultivation.

Several research have been performed, principally on the properties of artemisinin and its derivatives while not as much of studies were performed on agro-techniques, especially in Italy were only a few reports have been published. In United States (Simon et al., 1990) reports yield values ranging from 21 to $35 \mathrm{t} \mathrm{ha}^{-1}$ of fresh matter, according to density (from 2.8 to 11.1 plants $\mathrm{m}^{-2}$ ), while the $\mathrm{N}$ supply did not show evident increases in production, and so was observed in the Salento experiment here described. In India, (Kumar et al., 2003) report maximum values of yield analogous to U.S.A. trial for a crop receiving supplemental irrigation, at a density of 7.0 plant $\mathrm{m}^{-2}$ and supplied with $80 \mathrm{Kg}$ of $\mathrm{N} \mathrm{ha}^{-1}$.

The data published in the agronomic literature, obtained with different genotypes, confirm our results in which Artemisia production is largely affected by plant density than by nitrogen rate.

It is out of doubt that in the semi-arid environments of the Mediterranean regions the yield levels of Artemisia are strongly dependent on the soil water regime.

An appropriate irrigation scheduling, and at a less extent the plant density, allow to double the biomass. Here more than $65 \mathrm{t} \mathrm{ha}^{-1}$ were harvested from well watered and properly spaced crops, while at low density and with low water supply harvest was about the half of the maximum yield that coincides with the highest productions reported in literature.

Nevertheless, it is still an unsolved question whether the higher productivity levels reported in this study, and those reported in technical local reports (Interlandi et al., 2007; Greco et al., 2007), are due to the improved genotypes or to better crop management.

\section{Conclusions}

The analysis of the observations collected by this research indicates that in the Mediterranean environment Artemisia meets the favourable condition to grow and produce. The industry expectation was also satisfied.

Results from this two-year field study allow indicating the basic agrotechniques to start Artemisia cultivation in Mediterranean areas. Irrigation water availability is a pre-requisite for its cultivation. Full irrigation do not seem necessary, however supplemental irrigation appears to be the best strategy in order to overcome period of soil water drought. Moderate irrigation volumes, not less than $150 \mathrm{~mm}$ season ${ }^{-1}$, should be available for growing this species in semi-arid environments. Low Nitrogen application (not higher than $60 \mathrm{Kg} \mathrm{ha}^{-1}$ ) is enough, however the exact $\mathrm{N}$ amount to supply depends on the soil availability and the place of the Artemisia within the crop rotation. A planting density of 7-8 plant $\mathrm{m}^{-2}$ allows good results in term of biomass and artemisinin content.

In these two years of trials, Artemisia denoted an excellent adaptability in southern Italy climate areas, revealing to be quite easy to grow, with no pest or disease occurring during cultivation. The adoption of this species in organic farming systems seems highly possible.

Future agronomic research should be focused on the mechanization (such as transplanting, weed control and harvest) and on the test of a wider range of genotypes and their interactions with the main agro-techniques examined here.

\section{References}

Acton N., Klayman D.L., 1985. Artemisinin, a new sesquiterpene lactone endoperoxide from Artemisia annua. Planta Med. 51:441-442.

Acton N., Klayman D.L., Rollman I.J., 1985. Reductive electrochemical HPLC assay for artemisinin (qinghaosu). Planta Med. 51:445-446.

Bagchi G.D., Jain D.C., Kumar S., 1997. Arteether: a potential growth inhibitor from Artemisia annua. Phytochemistry 45:1131-1133.

Balint G.A., 2001. Artemisinin and its derivatives. An important new class of antimalarial agents. Pharmacology and Therapeutics 90:261-265.

Basso F., 2009. Piante officinali aromatiche e medicinali, aspetti bioagronomici aromatici e fitoterapeutici. Patron Ed., Padova, Italy.

Bailey L.H., Bailey E.Z. 1976. Hortus third. MacMillan Publ. Co., New York, NY, USA.

Charles D.J., Cebert E., Simon J.E., 1991. Characterization of the essential oils of Artemisia annua L., J. Ess. Oil Res. 3:33-39.

Charles D.J., Simon J.E., Wood K.V., Heinstein P., 1990. Germplasm variation in artemisinin content of Artemisia annua using an alternative method of artemisinin analysis from crude plant extracts. J. Nat. Prod. 53:157-160.

Charles D.J., Simon J.E., Shock C.C., Feibert E.B.G., Smith R.M., 1993. Effect of Water Stress and Post-Harvest Handling on Artemisinin Content in the Leaves of Artemisia annua L., New crops. Wiley \& Sons, New York, NY, USA.

Chen P.K., Leather G.R., Klayman D.L., 1987. Allelopathic effect of artemisinin and its related compounds from Artemisia annua. Plant Physiol. 83S:Abstr.406.

Davies M.J., Atkinson C.J., Burns C., Woolley J.G., Hipps N.A., Arroo R.R., Dungey N., Robinson T., Brown P., Flockart I., Hill C., Smith L., Bentley S., 2009. Enhancement of artemisinin concentration and yield in response to optimization of nitrogen and potassium supply to Artemisia annua. Ann. Bot-London 104:315-323.

Delabays N., Benakis A., Collet G., 1993. Selection and breeding for high artemisinin (qinghaosu) yielding strains of Artemsia annua. Acta 
Artemisia (Artemisia annua L.). Risultati finali del progetto C0.Al.Ta., pp 529-533.

Gupta S.K., Singh P., Bajpai P., Ram G., Singh D.,. Gupta M.M., Jain D.C., Khanuja S.P., Kumar S., 2002. Morphogenetic variation for artemisinin and volatile oil in Artemisia annua. Ind. Crop. Prod. $16: 217-224$

Hall H.M., Clements F.E., 1923. The phylogenetic method in taxonomy. The North American species of Artemisia, Chrysothamnus and Atriplex. Carnegie Institution of Washington Publ., Washington, DC, USA.

Laughlin J.C., 1995. The influence of distribution of antimalarial constituents in Artemisia annua L. on time and method of harvest. Acta Hort. 390:67-73.

Liersch R., Soicke H., Stehr C., Tüllner H.U., 1986. Formation of artemisinin in Artemisia annua during one vegetation period. Planta Med. 52:387-390.

McVaugh R., 1984. Compositae. In: W.R. Anderson (ed.) Flora NovoGaliciana: a descriptive account of the vascular plants of Western Mexico, Vol. 12. University of Michigan Press, Ann Arbor, MI, USA.

Marchese J.A., 2010. Water deficit effect on the accumulation of biomass and artemisinin in annual wormwood (Artemisia annua L., Asteraceae). Braz. J. Plant Physiol. 22:1-9.

Marzi V., De Mastro G., 2008. Piante officinali: coltivazione, trattamenti di post-raccolta, contenuti di principi attivi, impieghi in vari settori industriali ed erboristici. Adda Ed., Bari, Italy.

Morales M.R., Charles D.J. Simon J.E., 1993. Seasonal accumulation of artemisinin in Artemisia annua L. Acta Hort. 344:416-420.

Pras N., Visser J.F., Batterman S., Woerdenbag H.J., Malingré T.M. Lugt C.B., 1991. Laboratory selection of Artemisia annua L. for high artemisinin yielding types. Phytochem. Anal. 2: 80-83.

Ram M., Gupta M.M., Dwivedi S., Kumar S. 1997. Effect of plant density on the yields of artemisinin and essential oil in Artemisia annua cropping under low input cost management in North-Central India. Planta Medica 63:372-374.

Schmid, G., Hofheinz W., 1983. Total synthesis of qinghaosu. J. Am. Chem. Soc. 105:624-625.

Shock C.C., Stieber T.S. 1987. Productivity of Artemisia annua in the Treasure Valley. Oregon State Univ. Special Rpt. 814: 115-123.

Simon J.E., Charles D., Cebert E., Grant L., Janick J. Whipkey A. 1990. Artemisia annua L.: A promising aromatic and medicinal. In: J. Janick and J.E. Simon (eds.) Advances in New Crops. Timber Press, Portland, OR, USA.

Singh A., Vishwakarma R.A., Husain A. 1988. Evaluation of Artemisia annua strains for higher artemisinin production. Planta Med. 54:475-476.

Wallaart T.E., Pras N., Beekman A.C., Quax W.J. 2000. Seasonal variation of artemisinin and its biosynthetic precursors in plants of Artemisia annua of different geographical origin: Proof for the existence of chemotypes. Planta Med. 66:57-62.

Woerdenbag H.J., Pras N., Bos R., Visser J.F., Hendriks H., Malingré T.M., 1991. Analysis of artemisinin and related sesquiterpenoids from Artemisia annua L. by combined gas chromatography/mass spectrometry. Phytochem. Anal. 2:215-219.

Woerdenbag H.J., Pras N., Chan N.G., Bang B.T., Bos R., Van Uden W., Van Y. P., Boi N.V., Batterman S., Lugt C.B., 1994. Artemisinin, related sesquiterpenes, and essential oil in Artemisia annua during a vegetation period in Vietnam. Planta Med. 60: 272-275.

Zhou W.S., 1986. Total synthesis of arteannuin (quinghaosu) and related compounds. Pure Appl. Chem. 58:817-824. 